Monika Parchomiuk

Instytut Pedagogiki

UMCS W LUBLINIE

E-MAIL: MONIKA.PARCHOMIUK@POCZTA.UMCS.LUBLIN.PL

\title{
STAROŚĆ I STARZENIE SIĘ W PERCEPCJI OSÓB Z NIEPEŁNOSPRAWNOŚCIĄ INTELEKTUALNĄ
}

\section{Wprowadzenie}

Dane z badań realizowanych w krajach zaawansowanych pod względem organizacji opieki i rehabilitacji informują o systematycznym wydłużeniu okresu życia osób z długotrwałą niepełnosprawnością, w tym intelektualną [Barr, Gilgunn, Kane, Moore, 1999: 1483; Strydom, Hassiotis, Livingston, 2005: 229]. Należy jednak mieć na uwadze, że jest to ogólna tendencja. Długość życia, jego jakość oraz charakter i przebieg procesu starzenia się są osobniczo zróżnicowane i podlegają działaniu czynników biologicznych oraz środowiskowych. W tym zakresie można mówić o pewnej specyfice w odniesieniu do populacji niepełnosprawnych intelektualnie, przy jednoczesnym występowaniu tendencji niespecyficznych, a zatem podobnych czy tożsamych z występującymi u osób w normie intelektualnej. Obecność zespołów zaburzeń lub schorzeń, w tym uwarunkowanych genetycznie (np. zespół Downa, zespół Pradera-Williego, Williamsa, mózgowe porażenie dziecięce), wiąże się z szybszymi, bardziej dynamicznymi i silniej zarysowanymi zmianami o charakterze biopsychofizycznym [Coppus, 2013: 7-12; Dykens, 2013: 77-80]. Znaczenie tego typu zaburzeń należy jednak rozważać w kontekście uwarunkowań środowiskowych, w tym miejsc, form, stylów życia niepełnosprawnych intelektualnie, czy istotnych wydarzeń życiowych. Badania dowodzą, że wymienione czynniki mogą być specyficzne w przebiegu życia osób $\mathrm{z}$ tej populacji, jednak nie można jednoznacznie i globalnie ocenić ich znaczenia z perspektywy zdrowia i jakości życia [Lifshitz, Merrick, 2003; 2004; 
Patti, Amble, Flory, 2005]. Zarówno instytucjonalizacja, w tym całożyciowa, rozumiana nie tylko $\mathrm{w}$ kategoriach zamieszkiwania $\mathrm{w}$ domach opieki, ale również wszelkich innych formach pozarodzinnych, jak i życie rodzinie determinują określone ograniczenia i możliwości kształtujące w pewien sposób potencjał indywidualny człowieka $\mathrm{z}$ niepełnosprawnością intelektualną.

Wzrost populacji osób starych z niepełnosprawnością intelektualną rodzi konieczność podejmowania działań zmierzających do zapewnienia optymalnych warunków ich życia, uwzględniających tradycyjne idee i postulaty dotyczące podstaw rehabilitacji i wsparcia, jak normalizacja, integracja, podejście skoncentrowane na osobie czy empowerment, ponadto współczesne tendencje w polityce zdrowotnej, przykładem których jest idea aktywnego starzenia się. Należy przy tym pamiętać o kompleksowości i indywidualizacji odnoszącej się do wspomnianych wcześniej uwarunkowań osobniczych i środowiskowych. W centrum opisanych założeń pozostaje potrzeba analizowania doświadczeń samych zainteresowanych, tj. osób z niepełnosprawnością. Systematycznie zwiększa się zakres badań uwzględniających przeżycia, postawy i potrzeby niepełnosprawnych intelektualnie w związku ze starością, tak oczekiwaną, jak i faktyczną. W zakresie analizowanej problematyki znajdują się takie kwestie, jak: sposoby rozumienia starości oraz jej definiowania przez osoby z niepełnosprawnością intelektualną [Lifshitz, 2002; Boulton-Lewis, Buys, Tedman-Jones, 2007; Innes, McCabe, Watchman, 2012], problemy doświadczane $\mathrm{w}$ wieku starszym, plany i obawy wiązane z przyszłością [Hole, Stainton, Wilson, 2010; Buys, Aird, Miller, 2012], znaczące wydarzenia życiowe [Patti, Amble, Flory, 2005], doświadczanie autonomii oraz barier w jej realizacji [Buys, Tedman-Jones, 2004; Lehmann, Bos, Rijken, Cardol, Peters, Kok, Curfs, 2013]. Uzyskane dotychczas rezultaty pozwalają wskazać na następujące tendencje:

- $\quad$ osoby z niepełnosprawnością intelektualną mają stereotypowy obraz starości, w którym dominują ograniczenia w zakresie zdrowia i sprawności oraz życiowej aktywności;

- $\quad$ w wieku starszym wykazują potrzebę autonomii i bycia aktywnymi, ale doświadczają barier zewnętrznych w ich realizacji;

- osoby niepełnosprawne intelektualnie mają małe możliwości decydowania o sposobach i miejsca życia na przestrzeni swojej egzystencji, często nie są przygotowywane do zmian w tym zakresie, nie mają sposobności ujawniania swoich preferencji i potrzeb;

- $\quad$ w związku z powyższym doświadczają obaw i lęków w odniesieniu do swojej przyszłości [Lifshitz, 2002; Buys, Tedman-Jones, 2004; Buys, Boul- 
ton-Lewis, Tedman-Jones, Edwards, Knox, Bigby, 2008; Hole, Stainton, Wilson, 2010; Judge, Walley, Anderson, Young, 2010].

Należy jednak podkreślić, że opisane wnioski z badań różnych autorów odnoszą się do populacji osób zamieszkujących w krajach o ugruntowanej polityce niepełnej sprawności, m.in. Wielkiej Brytanii, Stanów Zjednoczonych czy Australii, w których procesy normalizacji i integracji są zaawansowane, podobnie jak deinstytucjonalizacja, empowerment, self-adwokatura zmierzające do ich osiągnięcia. Problematyka starzenia się niepełnosprawnych intelektualnie jest słabo rozpoznana na gruncie polskim. Badania $\mathrm{z}$ udziałem dorosłych niepełnosprawnych intelektualnie, wzbogacone o wnioski z dotychczasowych eksploracji zagadnienia starości i starzenia się tej populacji, mogą dostarczyć podstaw dla sformułowania założeń istotnych z perspektywy edukacji i rehabilitacji, opartych na ideach całożyciowego planowania i działań skoncentrowanych na osobie.

\section{Założenia badań własnych}

Celem badań będzie poznanie wiedzy i opinii dorosłych niepełnosprawnych intelektualnie na temat starości oraz procesu starzenia. Problematyka badawcza koncentruje się na ustaleniu:

- jakie są doświadczenia badanych związane z osobami starymi;

- $\quad$ w jaki sposób osoby te postrzegają starość, jakie cechy specyficzne jej nadają, zwłaszcza w aspekcie psychofizycznym oraz w kontekście aktywności i zadań życiowych, potrzeb wsparcia, ponadto towarzyszących jej ograniczeń i trudności;

- jakie są opinie badanych na temat potencjalnych działań ważnych z perspektywy optymalnego starzenia się (wynikających z określonego stylu życia i zachowań zdrowotnych);

- jakie są wyobrażenia niepełnosprawnych intelektualnie dorosłych o własnej przyszłości związanej z tym okresem życia, w tym m.in. preferencje miejsca i sposobu egzystencji czy pożądanych form aktywności.

Badania są osadzone $\mathrm{w}$ paradygmacie jakościowym, który pozwoli na ujęcie całościowe problematyki, z uwzględnieniem jej kontekstu jako istotnego źródła wiedzy i opinii badanych na temat starości i starzenia się, ponadto ujawnienie sensów, znaczeń, interpretacji badanych niepełnosprawnych intelektualnie zawartych $\mathrm{w}$ relacjonowanych opiniach oraz wiedzy. 
W celu zebrania materiału badawczego zastosowano metodę wywiadu indywidualnego półstandardowego (semi-structured), wykorzystywaną przez wielu badaczy w tym obszarze problemowym [Boulton-Lewis, Buys, Tedman -Jones, 2007; Buys, Boulton-Lewis, Tedman-Jones, Edwards, Knox, Bigby, 2008; Judge, Walley, Anderson, Young, 2010]. Tego typu metoda zbierania danych pozwoliła zaktywizować wypowiedzi badanych w kierunku relacjonowania własnych doświadczeń oraz związanych z nimi wiedzy i opinii. $\mathrm{Z}$ drugiej zaś strony umożliwiła badaczowi zebrać te dane, które są niezbędne z perspektywy założonego celu badań [Konarzewski, 2000].

Wywiady przeprowadzono $\mathrm{z}$ udziałem sześciu intencjonalnie dobranych osób dorosłych $\mathrm{z}$ niepełnosprawnością intelektualną, obojga płci, dysponujących takim poziomem sprawności poznawczych oraz umiejętności komunikacyjnych, który pozwolił im na zaangażowanie w rozmowę $\mathrm{z}$ badaczem. Istotnym kryterium udziału była zdolność udzielenia świadomej zgody oraz motywacja badanych do dzielenia się swoimi doświadczeniami. Badania zostały zrealizowane przez autorkę opracowania na terenie miasta Lublina $\mathrm{w}$ warsztatach terapii zajęciowej. Indywidualne spotkania z badanymi poprzedzone były uzyskaniem zgody ze strony kierownictwa instytucji oraz samych niepełnosprawnych intelektualnie. Zgoda osób niepełnosprawnych dotyczyła również rejestrowania materiału za pomocą dyktafonu. Średni czas trwania wywiadu wynosił jedną godzinę. Pytania zasadnicze dla problematyki poprzedzała swobodna rozmowa służąca m.in. poznaniu intencji badacza, nawiązaniu relacji z badanym ${ }^{1}$, uzyskaniu o nim podstawowych informacji. Dane o badanych zestawiono w tabeli 1.

Tabela 1. Charakterystyka badanych osób

\begin{tabular}{|c|c|}
\hline Badani & Dane \\
\hline Kobieta 1 & $\begin{array}{c}\text { wiek: 33 lata, zamieszkuje w mieście wojewódzkim z siostrą i jej rodzi- } \\
\text { ną, matka zmarła, z ojcem nie ma kontaktu, ukończona szkoła zawodo- } \\
\text { wa ogólnodostępna, podejmowała praktyki zawodowe }\end{array}$ \\
\hline
\end{tabular}

1 Badanym zaproponowano formę zwracania się po imieniu w obustronnej relacji. Wszyscy wyrazili zgodę, jednak jedna z kobiet w swoich wypowiedziach wracała do formy grzecznościowej „pani”. 


\begin{tabular}{|c|c|}
\hline Kobieta 2 & $\begin{array}{c}\text { wiek: 23 lata, obecnie od kilku miesięcy zamieszkuje w mieście woje- } \\
\text { wódzkim w mieszkaniu chronionym, ma matkę i brata, ukończona szkoła } \\
\text { zawodowa specjalna, nigdy nie pracowała, zarejestrowana w urzędzie } \\
\text { pracy }\end{array}$ \\
\hline Kobieta 3 & $\begin{array}{r}\text { wiek: 33 lata, zamieszkuje w mieście wojewódzkim, z ojcem i rodzeń- } \\
\text { stwem, ukończona szkoła zawodowa specjalna, nigdy nie pracowała } \\
\text { i nie podejmowała prób znalezienia pracy }\end{array}$ \\
\hline Mężczyzna 1 & $\begin{array}{r}\text { wiek: 40 lat, zamieszkuje w mieście wojewódzkim z rodzicami i babcią, } \\
\text { ukończona szkoła zawodowa specjalna, od 17 lat w warsztatach terapii } \\
\text { zajęciowej (WTZ), nigdy nie pracował i nie szukał pracy }\end{array}$ \\
\hline Mężczyzna 2 & $\begin{array}{r}\text { wiek: 30 lat, zamieszkuje w mieście wojewódzkim z rodzicami, ukoń- } \\
\text { czona szkoła zawodowa specjalna, nigdy nie pracował i nie szukał pracy }\end{array}$ \\
\hline Mężczyzna 3 & $\begin{array}{c}\text { wiek: 35 lat, zamieszkuje w mieście wojewódzkim z mamą, babcią i ro- } \\
\text { dzeństwem, ojciec nie żyje, ukończona szkoła podstawowa specjalna, od } \\
15 \text { lat w WTZ, nigdy nie pracował i nie szukał pracy }\end{array}$ \\
\hline
\end{tabular}

\section{Wiedza i opinie badanych na temat starości i starzenia się}

Zebrany materiał zostanie zaprezentowany zgodnie z założoną problematyką będącą podstawą strukturyzacji wywiadu. Na wstępie dokonano analizy doświadczeń respondentów związanych z ich kontaktami z osobami w starszym wieku, uznając, że są one istotne dla kształtowania ich wiedzy oraz opinii na temat tego okresu życia, ponadto projektowania pewnych wyobrażeń na temat własnej przyszłości.

\section{Kontakty badanych z osobami starszymi}

W życiu badanych pojawiają się czy pojawiały znaczące osoby starsze. Należą do nich dziadkowie i inni krewni. Rola dziadków jest szczególna, bowiem mieli oni znaczny udział w wychowaniu respondentów, a niekiedy, przynajmniej czasowo, dominujący w zastępstwie rodziców. Kontakty ze starszymi krewnymi są obecnie zróżnicowane pod względem częstości, czasem ograniczają się do pomocy w czynnościach codziennych, ale również obejmują wspólne zamieszkiwanie i dzielenie trudności związanych $\mathrm{z}$ opieką nad starszą osobą chorą.

Badani spontanicznie nie wskazywali na kontakty przypadkowe ze starszymi ludźmi (np. w środkach komunikacji), ale zagadnięci przez badacza 
potwierdzali występowanie takich sytuacji. Odnosili się do nich również odpowiadając na pytanie, jaki jest ich udział w pomocy osobom starszym:

„W autobusie, jak, w autobusie starszej pani pomogłam, z zakupami, chociaż ja młoda jestem, ale miałam też operację na wyrostek i nie moge dźwigać, pomogłam, ale do pewnego rejonu, nie, nie do końca. W sensie nie do końca, tylko kawałeczek, poniosłam tą siatkę, czy pomogłam”. (Kobieta 3); „W otworzeniu drzwi. W zanoszeniu zakupów” (Mężczyzna 2); „Raz pomogłem. Bo chciałem zaprowadzić do domu. Powiedziałem: pomóc coś? Starsza powiedziała: tak. To do mieszkania." [A dlaczego pomogłeś tej pani?] „Bo robiła zakupy, a ja jej zaniosłem do mieszkania.” (Mężczyzna 3)

Relacje z osobami starszymi są oceniane jako pozytywne, przynoszące zadowolenie czy motywujące do dalszych spotkań, jednak rzadko wiążą się z międzypokoleniową wymianą wiedzy:

[Dlaczego lubisz spotykać się z osobami starszymi?] „Bo milsi są, a czasami, milsi są od tych młodszych, czasami, nie. Porozmawiać z nimi można spokojnie o wszystkim." (Kobieta 3)

„Mam taką koleżankę. Właśnie ta koleżanka ma 60 lat, to można powiedzieć, że to jest babcia dla mnie. (...) I wie Pani, no ja tą koleżankę po prostu lubię. No, bo to jest u mnie taka sytuacja, że ja jak chodziłam do szkoły podstawowej, do szkoły średniej, nigdy nie miałam koleżanek. Zawsze te koleżanki ze mnie się śmiały, że ja się zachowuję jak starsza osoba. I ja po prostu nie umiem $\mathrm{z}$ takimi ludźmi się dobrze dogadywać. Ja bardzo dobrze, ponieważ mieszkałam z dziadkiem. Ja bardzo dobrze z dziadkiem się dogadywałam, z babcią się dogadywałam. Ja właśnie z takimi ludźmi starszymi bardzo dobrze. Mam taką koleżankę, tak jak mówię, ona ma 60 lat. Co prawda to jest dla mnie babcia, ale ja ją traktuję wie Pani życzliwie. (...) Widzę, że ja z takimi ludźmi, może to nie jest dla mnie towarzystwo, ale po prostu nie wiem, umiem $z$ takimi ludźmi dobrze się dogadywać, jakoś. Ja uważam, że człowiek starszy to jest bardziej mądrzejszy, bo teraz to jest takie towarzystwo, że no, wie pani, są różni ludzie. Jeden jest taki, a drugi taki. Starsza osoba to ani mnie nie oszuka, ani, wie pani, o co chodzi. (...) Ja mam takie korzyści, że ja się uczę od tych ludzi, po prostu rozumu, odpowiedzialności”. (Kobieta 1)

Badani nie rozmawiają i nie rozmawiali ze swoimi dziadkami na temat wydarzeń minionych lat, kontakty te nie są też dla nich źródłem porad dotyczących rozwiązywania problemów życiowych. 


\section{Postrzeganie starości}

Badani niepełnosprawni intelektualnie sytuują początek starości w różnym wieku życia - po 50,60, 70 czy 80. Mają ograniczoną wiedzę na temat jej cech specyficznych. Dostrzegają przede wszystkim fizyczne objawy w postaci zmarszczek na twarzy, osłabienia siły czy ograniczenia sprawności:

„Stary? Że ma zmarszczki, czy co na twarzy” (Kobieta 3); „No, że już chodzi powoli, chodzi o lasce.” (Mężczyzna 2); „Bo ma laskę (...). Marszczy się. (...) Garbaty jest.” [A dlaczego chodzi o lasce?] „Bo jest ten... stary... bo już nie ma sił.” (Mężczyzna 1); „Po twarzy, coś boli, o lasce co chodzą.” (Kobieta 2)

Badanym trudno jest określić specyfikę tego okresu życia odnosząc się do form aktywności człowieka, jakkolwiek dostrzegają, że z wiekiem następuje ich zmiana, czy raczej ograniczenie. Starość łączą z rezygnacją z pewnych czynności:

„Na pewno z tego, z ćwiczeń (...) Z ćwiczeń intensywnych, żeby się nie przemęczać na przykład, bo wiadomo, że organizm starszy jest słabszy, serce wiadomo.” (Kobieta 3); „No...no, teraz [na starość] to co innego” (Mężczyzna 2); „Bo młody se chodzi na imprezę, a stary to już siedzi w mieszkaniu” (Mężczyzna 1); „Więcej odpoczywają” (Kobieta 2); „Na pewno innymi, bo jak jest człowiek młody to inaczej jest, prawda inne tam się rzeczy robi, czy coś takiego. Jak człowiek jest starszy, to nie wiem, no też można i na zabawę pójść i tu, no wiem pani. Człowiek starszy to jest już taki bardziej zmęczony. Potrzebuje więcej odpoczynku.” (Kobieta 1); „Wnukami się zajmują." (Kobieta 2)

Istotne znaczenie dla określenia specyficznych dla starości form aktywności ma odwołanie się do własnych doświadczeń wynikających z kontaktów z osobami bliskimi (dziadkami czy innymi starszymi członkami rodzin). Badani opisują, jakie są/ były codzienne zajęcia i czynności przez nich realizowane:

„Siedzą, siedzą w domu [A co dziadkowie robią w domu?] No... rozwiązują krzyżówki. Spotykają się z sąsiadami." (Mężczyzna 2) [A twoi dziadkowie co robili?] „W polu.” (Kobieta 2)

Badani nie są świadomi, że starość może się łączyć z koniecznością zaprzestania pracy. Na pytanie, czy starsi ludzie pracują odpowiadają twierdząco, długo się zastanawiają podając odpowiedź przeczącą, ale nie mając w tym względzie pewności. Odpowiadają, że starsi ludzie nie mają już obo- 
wiązków. W jednej z wypowiedzi pojawiło się stwierdzenie, że starsi ludzie pobierają rentę.

U starszych ludzi dostrzegana jest zmiana zachowania czy specyficzne cechy:

„Narzekają [Na co?] Na starość, nie, stary jestem, coś takiego mówią.” (Kobieta 3); „No... są spokojniejsi. No..., no... mają dobry humor. ” (Mężczyzna 2); „No, inaczej się zachowują. Jak ich bolą nogi, to trzeba miejsca ustąpić. Pomóc w zakupach nieść.” (Kobieta 2); „Mi się wydaje, że z wiekiem człowiek tak jakby dojrzewa do pewnych spraw, $\mathrm{z}$ wiekiem.” [Do jakich spraw?] „No, o takich, wie pani, do takich, no nie wiem, do dorosłości, odpowiedzialności." (Kobieta 1)

Specyfika zachowania wynikać może z choroby (Alzheimera), która była udziałem starszego członka rodziny:

[To jest bardzo trudna choroba] „To jest straszna” [W czym się ona przejawia?] „Że ten... że traci się pamięć... ." (Mężczyzna 1). W trakcie rozmowy badany szczegółowo opisuje wypadek, który zdarzył się w jego domu w związku z chorobą babci. Retrospekcji tego wydarzenia towarzyszą silne emocje i motywacja do przekazania informacji badaczowi.

Badani potwierdzają, że osoby starsze mają specyficzne problemy, jednak nie zawsze potrafią je skonkretyzować. Najczęściej, co jest zbieżne z postrzeganą specyfiką tego okresu życia, wcześniej opisywaną, trudności dostrzegają w ograniczeniach siły i sprawności fizycznej:

„Człowiek stary, (dłużej się zastanawia) z czym sobie nie radzi? Na przykład coś napisać, coś trudnego, czy coś to napisać, jak prosi tego kogoś, czy wnuczka, czy co, kogoś młodszego nie, jakieś, czy do apteki, czy coś. Jak nie rozczyta na recepcie, nie. Bo czasami lekarze tak piszą, że się nie rozczyta nawet zdrowy człowiek, zdrowy na umyśle" [Co się pogarsza jeszcze na starość?] „Zdrowie, wiadomo, że zdrowie. Zdrowie (namyśla się), nie? Z kondycją. Zdrowie, kondycja” (Kobieta 3); [Czy są jakieś kłopoty ze zdrowiem?] „Problemy z kręgosłupem. Z poruszaniem się” (Mężczyzna 2); [Z czym ma problemy stary człowiek?] „Z pomocą?” [Co to znaczy, że ma problemy z pomocą?] „Trzeba coś pomóc, coś tam. W szpitalu coś.” (Mężczyzna 3); „Ze wzrokiem, ze zdrowiem.” (Kobieta 2); „Na przykład to może mieć ze zdrowiem jakieś tam problemy, no nie?” (Kobieta 1)

Ograniczenia $\mathrm{w}$ zakresie sfery umysłowej nie są spontanicznie wymieniane przez badanych i dopiero pytanie badacza ukierunkowujące na tę kwestię prowadzi do ich uznania jako specyficznych problemów wieku starszego: 
„Pamięć, też, szwankować może w tym wieku.” (Kobieta 3); „Problemy z koncentracją." (Mężczyzna 2)

Niekiedy pomocne jest odwołanie się do własnych doświadczeń związanych z funkcjonowaniem starszych członków rodziny. Badani wymieniali, jakie czynności codzienne sprawiają, czy sprawiały tym osobom trudności, w zakresie jakich wymagają pomocy, również ze strony swoich wnuków/ krewnych. Opisywali przejawy problemów zdrowotnych, tak fizycznych, jak i psychicznych (kłopoty z pamięcią):

„No ja nie wiem. Mój dziadek to miał na przykład takie problemy z moczem. On miał... On brał jakiś lek, Prostamol czy coś tam. No różne, z sercem mogą mieć problemy, mój dziadek to miał jeszcze takie krążeniowe, że on taki, że go nogi te stawy bolały." (Kobieta 1); [A czy człowiek stary może mieć problemy z pamięcią?] „Moja babcia miała, dziadzio też. Dziadzio aż uciekał z domu." (Kobieta 2)

Adekwatnie do postrzeganych problemów i ograniczeń w zakresie codziennej aktywności, mówiąc o potrzebie wsparcia starszych osób badani koncentrują się na jego wymiarze praktycznym:

„Stary człowiek? No, żeby go umyć. Na przykładzie mówię cioci, która jest tego. Umyć, dokładnie, pielęgnacja wokół tej osoby. Umyć, uczesać, żeby ładnie wyglądała, nie tak wiesz staro, czy coś. Tylko żeby jakoś wyglądała, jak się przyjdzie na przykład, tego do domu, to żeby jakoś przygotować tą osobę. Nap przykład przy, no, jak się, jak się, tej osobie, no, chodzi o służbę zdrowia teraz, nie. Jak się tej osobie starszej coś dzieje, nie, to żeby ktoś był taki młodszy, żeby z nią pojechał, ewentualnie coś załatwił. Wiadomo, że może sobie nie poradzić.” (Kobieta 3); [Jakiej pomocy może potrzebować stary człowiek?] „Z zakupami.” (Mężczyzna 3); „Spokoju, ciszy. Na przykład jak nogi go bolą, albo co tam, żeby nasmarował, albo nie wiem co jeszcze. W zakupach." (Kobieta 2)

Określenie potrzeb wsparcia osób starych przychodzi jednak badanym $\mathrm{z}$ trudnością, a w ich odpowiedziach na pytanie - Czego mogą potrzebować osoby stare? - pojawia się ogólne sformułowanie - opieki.

Konkretyzacja źródeł wsparcia jest trudna, zwłaszcza jeśli chodzi o wymiar instytucjonalny. W wypowiedziach osób niepełnosprawnych intelektualnie pojawiły się tylko domy pomocy społecznej jako instytucje pomocowe.

Badani spontanicznie nie wskazują na rodzinne/ przyjacielskie/ sąsiedzkie źródła wsparcia. Dopiero ukierunkowani pytaniami badacza potwierdzają, że to rodzina ma pomagać starszym jej członkom w codziennym 
funkcjonowaniu. W wypowiedzi jednej z kobiet pomoc osobom starszym została utożsamiona ze wsparciem ze strony rodziny:

„Wie pani, no starsza osoba powinna ze strony rodziny jakiegoś wsparcia potrzebować takiego. No przede wszystkim wsparcia."[Jakiego wsparcia?] „No to to jest takie, no ze strony rodziny, że człowiek nie czuje się sam, taki starszy człowiek to nie powinien się w starości sam czuć.” (Kobieta 1)

Domy pomocy społecznej, które są jedynymi znanymi badanym instytucjami pomocowymi, postrzegane są jako miejsce życia osób starszych. Niepełnosprawni intelektualnie, wskazując na instytucje opieki, posługiwali się różnymi określeniami: domy starości, domy starców, domy seniora, domy opieki, domy pomocy społecznej, nie zawsze traktując je w kategoriach synonimów. Jeden $\mathrm{z}$ respondentów wskazał na schroniska. Co ciekawe, w tym względzie badani nie zawsze potrafili odnieść się do własnych doświadczeń. Dodatkowe pytania badacza prowadziły do wniosku, że starsi ludzie, w tym członkowie własnej rodziny, mogą też zamieszkiwać w domach rodzinnych. Jedna $\mathrm{z}$ badanych potraktowała życie w instytucji jako alternatywę w tej sytuacji, kiedy rodzina nie podejmuje opieki nad osobą starszą:

[Czy znasz jakieś instytucje, gdzie starzy ludzie mogą zamieszkać?] „No są, jeśli rodzina jest taka, że na przykład chce zgodzić się, żeby taka osoba mieszkała, no a jak nie, to wtedy odda gdzieś." [A gdzie odda?] No do domu starców może oddać, do domu opieki może oddać." (Kobieta 1)

Badani proszeni o dokonanie oceny form życia starszych osób dostrzegali pozytywne aspekty funkcjonowania w rodzinie:

„Zawsze to przyjemnie jest.” (Mężczyzna 3); „Bo [babcia] jest przy córce.” (Mężczyzna 1); „Chyba w..., wydaje się, że lepiej w domu. Bo się lepiej zajmą niż w domu starców.” (Kobieta 2); „No wie pani, moim zdaniem to jeśli rodzina oddaje, to znaczy się moim zdaniem nie interesuje się, bo jeśli by chciała, to ja uważam, że... ." (Kobieta 1)

Ocena starości jako okresu życia jest mniej korzystna niż młodości:

„Bo młody, ja tak uważam, że jest taki energiczny bardziej od tego starszego. Starszy to wiadomo, już w starszym wieku to nie ma siły, nie ma tego, powoli chodzi czy coś, czy robi.” (Kobieta 3); „Lepiej być młodym.” [Dlaczego?] „Bo fajnie pójść z kimś. Pójść se z kimś na spacerek, do kina, na jakieś ciasteczko." (Mężczyzna 3)

Dodatkowe pytania badacza, nawiązujące do doświadczeń badanych, pozwalają im dostrzec pozytywne aspekty starości. Osoby niepełnosprawne wskazują na możliwość bycia razem (dziadków) oraz posiadanie wnuków. 
„No... (zastanawia się), no ...starość też ma swoje dobre strony.” [Jakie?] „No, pociechy z wnuków. Że się nie musi martwić... o zdrowie.” (Mężczyzna 2); „No koleżanka ta $\mathrm{z}$ [mieszkania chronionego] to ona zadowolona jest. Bo jej wie pani synowa włosy zrobi i umaluje, i ona przychodzi, i jest umalowana, i paznokcie umalowane, i wie pani i 60 ma lat, i zadbana, naprawdę. No moja babcia też miała 60 lat i bardzo ładnie wyglądała. To wcale nie przeszkadzało, że ma 60 lat i paznokcie zrobione i henna zrobiona (śmieje się). (...) Bo na przykład mojej siostry teściowa ma wie pani syna niepełnosprawnego i ta pani ma 60 lat, i to jest naprawdę kobieta pełna podziwu. Bo ona i ciasto sama upiecze, i jeszcze my przyjedziemy, i jeszcze dla nas obiad przygotuje, i tym właśnie chorym synem się zajmuje. A ta pani ma już 60 parę lat, a naprawdę sobie bardzo dobrze sobie daję radę. To wcale nie przeszkadza, że tyle ma lat, wie pani.” (Kobieta 1)

\section{Przygotowanie człowieka do starości w opiniach badanych}

To zagadnienie jest badanym prawie nieznane. Wiedzą, że starość dotyczy każdego człowieka, jednak samodzielnie nie potrafią wskazać działań i form aktywności życiowej istotnych dla zachowania zdrowia i kondycji. Dopiero sugerowane przez badacza zachowania zdrowotne związane $\mathrm{z}$ dietą, stosowaniem używek czy badaniami profilaktycznymi są przez badanych aprobowane jako korzystne dla pomyślnego starzenia się. Konkretne pytania i wskazówki prowadzą do wskazania przez nich wybranych zachowań:

„Nie jeść tłustych potraw.” (Mężczyzna 2); „Można by zdrowym nie paląc, nie pijąc." (Mężczyzna 3)

Badani w ograniczonym stopniu realizują pewne zachowania zdrowotne, konkretyzowane w pytaniach przez badacza, tłumacząc to brakiem potrzeb - „Mam dobrą przemianę materii.” (Mężczyzna 2); „No surówki sobię robie i jem. Chodzę sobie.” (Kobieta 2)

\section{Wyobrażenia badanych o własnej przyszłości}

Badani nie zastanawiali się nad własną starością. Ten odległy w kontekście ich wieku okres życia nigdy nie prowokował do tworzenia wyobrażeń. Zachęceni przez badacza $\mathrm{w}$ pewnym stopniu zechcieli opisać swoje preferencje dotyczące miejsca życia oraz form aktywności. W odpowiedziach respondentów pojawia się zamieszkiwanie $\mathrm{w}$ domu rodzinnym $\mathrm{z}$ matką. 
Uwaga badacza prowokowała do zastanowienia i przyznania, że nie będzie to możliwe $\mathrm{z}$ uwagi na różnicę wieku. W takich sytuacjach respondenci mówili o domu pomocy społecznej (domu seniora) jako miejscu swojego życia w okresie starości, nie sugerując możliwości zamieszkiwania z innymi członkami rodziny. Jeden $\mathrm{z}$ badanych wyraźnie zaznaczył niemożność pozostawania $\mathrm{z}$ dalszą rodziną: [Czy masz rodzeństwo?] „Ciotecznych. Ale wszyscy ożenili się.” [Nie potrafi odpowiedzieć na pytanie, czy mógłby z nimi mieszkać], spontanicznie dodaje: „Bo chrzestna mnie nie weźmie, bo sama jest chora." (Mężczyzna 1), a jedna z kobiet stwierdziła: „No ja nie wiem, czy ja bym chciała mieszkać, czy w domu opieki, czy z siostrą bym mieszkała. To tego nie wiem.” (Kobieta 1). Jedna z kobiet stanowczo zaprzeczyła możliwości zamieszkania w domu pomocy społecznej, a jej odpowiedź korespondowała $z$ negatywną oceną tej instytucji dokonaną w odniesieniu do realizacji pomocy osobom starszym.

Badane osoby nie wyobrażały sobie życia we własnej rodzinie prokreacji, ze współmałżonkiem czy wnukami, a zapytane o to nieśmiało potwierdzały taką potrzebę, nie rozwijając tematu, bądź zaprzeczały jej, podkreślając swoje ograniczenia związane ze współwystępującą chorobą (padaczka).

Badani nie zawsze byli świadomi, że osiągnięcie wieku starszego będzie się wiązać z opuszczeniem warsztatów, żadna z osób nie zasygnalizowała przejścia na emeryturę. Respondenci mieli problemy z konkretyzacją preferowanych na starość form aktywności. Ich wypowiedzi obrazują chęć realizacji zainteresowań, albo pomocy innym członkom rodziny: „Czytać książkę, spacerować, rozmawiać, głównie rozmawiać, nie?” [Z kim rozmawiać?] „Z ludźmi.” (Kobieta 3); „No... bym... bym miał swoją działkę.” [A i co byś na tej działce robił?] „No bym sa... Bym miał warzywa.” (Mężczyzna 2); [A co będziesz robił na starość?] „Siedział w domu.” [Siedział tylko i nic innego nie robił?] „Nie, filmy tylko.” [Na spacer, do kawiarni, do kina?] „Nie, już niekoniecznie.” (Mężczyzna 3); [Co byś robiła, jakbyś miała wnuki?] „To bym pomagała im. W chodzeniu na spacery, w gotowaniu." (Kobieta 2); „No mogłabym wie pani zajmować się jakimś wnukiem (śmieje się). Albo na drutach bym robiła." (Kobieta 1 )

\section{Podsumowanie i dyskusja}

Ustosunkowując się do postawionych problemów badawczych można stwierdzić, że: 
- Doświadczenia badanych osób niepełnosprawnych intelektualnie $\mathrm{z}$ osobami starszymi dotyczą przede wszystkim relacji rodzinnych, tj. kontaktów z dziadkami oraz dalszymi krewnymi. Częstość i jakość tych kontaktów jest obecnie zróżnicowana, w zależności od sytuacji życiowej oraz kondycji zdrowotnej starszego członka rodziny. Są one źródłem pozytywnych doświadczeń emocjonalnych, ale w ograniczonym zakresie płaszczyzną wymiany wiedzy.

- Starość w percepcji badanych osób wiąże się przede wszystkim ze zmianami fizycznymi następującymi $\mathrm{w}$ organizmie oraz ich skutkami w postaci ograniczenia form aktywności życiowej, zwiększenia potrzeby odpoczynku. Sugerowane wsparcie obejmuje przede wszystkim wymiar praktyczny - pomoc w realizacji czynności codziennych. Znaczne trudności respondenci mają ze sprecyzowaniem źródeł wsparcia, zwłaszcza formalnych, przypuszczalnie nie są one znane. Trzeba jednak stwierdzić, że badani potrafią wymienić formy opieki nad osobami starszymi, wskazując na domy pomocy społecznej.

- Zachowania człowieka i styl życia pozwalający na utrzymanie potencjału zdrowotnego przez długie lata są obszarem, w którym badani wykazywali największe trudności. Nie potrafili wyrazić w tej kwestii własnych opinii.

- Wyobrażenia o własnej przyszłości w starszej fazie życia, wzbudzane pytaniami badacza, były w małym stopniu skonkretyzowane. W wyobrażeniach tych pojawia się jako preferowana forma życia zamieszkiwanie $\mathrm{w}$ domu rodzinnym $\mathrm{z}$ matką (i babcią), czy jego alternatywa - w domu pomocy społecznej, brak jest wizji własnej rodziny pochodzenia oraz występują ubogie i raczej bierne formy spędzania czasu.

Po analizie zebranego materiału nasuwa się kilka wniosków. Wydaje się, że badane osoby niepełnosprawne intelektualnie mają ograniczoną wiedzę na temat ról społecznych pełnionych na różnych etapach życia. Starości nie łączą z zaprzestaniem aktywności zawodowej, przejściem na emeryturę, przemianą pokoleniową w zakresie realizacji opieki w rodzinie (podejmowanie opieki nad osobami starszymi przez młodszych członków rodziny oraz pomoc dziadków w opiece nad wnukami). W konsekwencji w ich wyobrażeniach o własnej przyszłości nie pojawia się możliwość podejmowania takowych ról i zadań. Czynnikiem, który może być tutaj ważny jest jednak nie tylko mała wiedza, ale również postrzegane u siebie ograniczenia związane ze stanem zdrowia czy samodzielnością życiową (utrzymanie 
domu, umiejętności niezbędne do prowadzenia gospodarstwa domowego). W wypowiedziach badanych, które nie dotyczą bezpośrednio tematyki starości, ale odnosiły się do ich doświadczeń, pojawiał się temat braku dostatecznych umiejętności, m.in. związanych z przygotowaniem posiłków oraz towarzysząca temu kwestia wyręczania przez bliskich. Jenkins [2010: 35] pisze, że „osobom z niepełnosprawnością intelektualną trudno jest rozpoznawać symbole i właściwości wieku starszego, ze względu na ograniczenia rozumienia procesów społecznych. Osoby te mają małe możliwości doświadczania wielu pozytywnych ról, jak bycie rodzicem, posiadanie pracy i wysokiego społecznego statusu w społeczeństwie."

Uzyskane tu wyniki częściowo potwierdzają ustalenia innych badaczy, jakkolwiek tego typu porównania należy przeprowadzać z ostrożnością, mając na względzie różne podstawy koncepcyjne czy aparat metodologiczny, ale nade wszystko fakt, że badane tutaj osoby nie osiągnęły jeszcze wieku starszego. Obraz form aktywności osób starszych, obserwowany i projektowany przez badanych dorosłych, jest ubogi i ogranicza się raczej do czynności niezbędnych w codziennym życiu, związanych z prowadzeniem domu, opieką nad wnukami. Dominuje jednak bierność i potrzeba odpoczynku. Badani nie zwrócili uwagi na to, że starość może być okresem realizacji zainteresowań i podejmowania aktywnych działań, co pewnie wynika z ich doświadczeń (obserwacji trybu życia starszych osób). W literaturze przedmiotu są doniesienia wskazujące na silną potrzebę bycia aktywnym u starszych osób z niepełnosprawnością intelektualną [Buys, Boulton-Lewis, Tedman-Jones, Edwards, Knox, Bigby, 2008; Judge, Walley, Anderson, Young, 2010] oraz postrzegania przez dorosłych $\mathrm{z}$ tą niepełnosprawnością starości jako okresu życia, który może cechować różnorodność form spędzania czasu wolnego [Hole, Stainton, Wilson, 2010].

Badane osoby ujawniają pewnego rodzaju niedojrzałość w postrzeganiu i ocenianiu pewnych faktów, m.in. związanych z pobytem w warsztatach $\mathrm{w}$ wieku starszym czy zamieszkiwaniem $\mathrm{z}$ matką (a nawet babcią) w podeszłym okresie życia, co może wynikać z ograniczeń poznawczych. Z drugiej strony jest to pewnego rodzaju przejaw potrzeby stabilności, utrzymania dotychczasowej sytuacji, która prawdopodobnie daje im poczucie bezpieczeństwa. Badania innych autorów z udziałem starszych osób z niepełnosprawnością intelektualną potwierdzają tendencję wskazującą na obawę przed znaczącymi zmianami życiowymi, związaną z utratą kontroli [Judge, Walley, Anderson, Young, 2010] oraz chęć kontynuowania w przyszłości obecnych form aktywności [Hole, Stainton, Wilson, 2010]. Projekto- 
wane zamieszkiwanie $\mathrm{w}$ domu pomocy społecznej można traktować jako wyraz braku alternatywy przy postrzeganej niemożności zamieszkiwania $\mathrm{z}$ innymi członkami rodziny. Ta opcja życia nie jest jednak widziana jako dobra, a jej wskazanie jest wyrazem pesymistycznej oceny własnych możliwości w zakresie założenia rodziny, posiadania partnera, dzieci i wnuków.

Doświadczenia badanych związane $\mathrm{z}$ rodzinnymi relacjami z osobami starszymi są źródłem ich opinii na temat starości, w pewnym stopniu także wiedzy, jakkolwiek jest ona ograniczona, a sama starość jest oceniana mniej korzystnie w stosunku do wcześniejszych okresów życia. Taki wniosek potwierdzają badania opisane w literaturze przedmiotu. Lifshitz [2010] ujawniła, że koncepcja starości u niepełnosprawnych intelektualnie jest kształtowana przez stereotypowe przekonania. Wiedza na temat tego okresu życia ogranicza się do sfery fizycznej i praktycznej (wskazywanie głównie ograniczeń funkcjonalnych związanych z tym okresem życia), a ogólny obraz jest negatywny, zwłaszcza u osób młodszych z niepełnosprawnością intelektualną. Co ciekawe jednak, porównanie wiedzy i opinii respondentów z różnych grup wiekowych (20-30 lat; 40-60 oraz powyższej 60) pokazało, że u osób starszych wiedza na temat starości jest trafniejsza, bogatsza, a ocena tego okresu życia bardziej korzystna.

\section{Zakończenie}

W kontekście analizowanej tu problematyki można zasugerować następujące kwestie:

- Potrzeba dążenia w procesie edukacji, rehabilitacji i wsparcia niepełnosprawnych intelektualnie do respektowania ich wyborów; rozwijanie świadomości w zakresie specyfiki procesu starzenia oraz okresu starości, ale również innych faz życia człowieka wraz z przypisanymi im zadaniami oraz rolami społecznymi; kształtowanie kompetencji niezbędnych do zachowania aktywności życiowej, przy jednoczesnym stwarzaniu sposobności dla jej podejmowania. Należy przy tym pamiętać o istotnym znaczeniu działań zamierzonych i planowanych. Ich rola wzrasta wobec ograniczeń związanych $\mathrm{z}$ samodzielnym uczeniem się, $\mathrm{w}$ tym przez doświadczenie. Istotna rola przypada instytucjom, jak szkoły różnego szczebla, warsztaty terapii zajęciowej, środowiskowe domy samopomocy oraz specjalistom $\mathrm{w}$ nich zatrudnionym. Niezbędne jest przy tym wsparcie ze strony rodziny, zwłaszcza bliskiej, która stoi wobec konieczności całożyciowego wspierania człowieka $\mathrm{z}$ niepełnosprawnością intelektualną. Warto podkreślić, 
jakkolwiek postulat ten nie jest nowy na gruncie pedagogiki specjalnej, że rozwijanie potencjału i redukowanie trudności jest najbardziej optymalne w swoich skutkach przy zachowaniu zasad wczesności, kompleksowości, ciągłości. Działania specjalistów, opiekunów, w tym członków rodziny, należy oprzeć na postulacie proaktywnego wsparcia. Oznacza on pomoc osobom w planowaniu i przygotowaniu do przyszłych zmian w życiowych sytuacjach [Innes, McCabe, Watchman, 2012].

- Systematyczne różnicowanie i poszerzanie zakresu wsparcia niezbędnego w dorosłości rozumianej w kategoriach procesu. Dotyczy to szczególnie oferty miejsc życia, której wybór powinien opierać się na czynnikach: kulturowych, potrzebach w zakresie opieki, osobistych preferencjach, dostępności usług, bieżących i przyszłych potrzebach zdrowotnych, potencjalnych konsekwencjach zmiany (dotychczasowej formy życia). Nie można opierać się wyłącznie na dychotomicznym podziale: opieka rodzinna - instytucjonalna (rozumiana w kategoriach instytucji tradycyjnych), bowiem nie wyczerpują one możliwości i potrzeb tej populacji (szczególnie związanych z autonomią). Należy jednak podkreślić, że nowa forma życia wymaga przygotowania, a okres starszy nie musi być optymalny do jego realizacji, zwłaszcza jeśli weźmie się pod uwagę mniejsze zdolności adaptacyjne człowieka w tym wieku. Chodzi więc o to, aby wybór adekwatnej do potrzeb formy życia przebiegał w perspektywie długoterminowej i był elementem tzw. całożyciowego i skoncentrowanego na osobie planowania usług i wsparcia.

Krause [2010: 117-124] pisze, że dorosłość niepełnosprawnych to wątek zaniedbany w pedagogice specjalnej, cechujący się licznymi niedoskonałościami i błędami na poziomie koncepcyjnym i organizacyjnym. Autor wspomina o niedostosowaniu oferty opiekuńczej do etapów dorosłości człowieka niepełnosprawnego, nadmiernej standaryzacji dorosłości tej populacji na skutek koncepcyjnego spłaszczenia życia jej reprezentantów oraz jednolitej oferty instytucjonalnej i infantylizacji. Ta ostatnia przyjmuje postać zwyczajowej (kulturowej), przejawianej najczęściej w rodzinach i w społecznym podejściu do niepełnosprawności (np. sposób zwracania się do ludzi dorosłych), instytucjonalnej i koncepcyjnej wyrażanej w brakach teoretycznych edukacji akademickiej, stylach i sposobach pracy w instytucjach oraz systemowym założeniu o obniżonej wydolności społecznej niepełnosprawnych. Te uwagi stanowią doskonałe podsumowanie zaprezentowanej problematyki. Dalsza jej eksploracja powinna zmierzać w kierunku poszerzania wiedzy na 
temat doświadczeń niepełnosprawnych intelektualnie związanych z dorosłością, ich potrzeb, trudności, oczekiwań dotyczących jej poszczególnych etapów, ustosunkowań do istniejących i planowanych rozwiązań wspierających (w tym wiedzy i motywacji do skorzystania). Należy przy tym podkreślić, że tak jak istotne jest poszerzanie wiedzy niepełnosprawnych, tak ważne jest również umożliwianie im wyrażania własnych preferencji. Oba te aspekty są elementami kluczowymi dla empowermentu jednostki.

\section{Bibliografia:}

Barr O., Gilgunn J., Kane T., Moore G. (1999), Health screening for people with learning disabilities by a community learning disability nursing service in Northern Ireland, "Journal of Advanced Nursing", t. 29 (6), s. 1482-1491.

Boulton-Lewis G., Buys L., Tedman-Jones J. (2007), Conceptions of aging and engagement in learning for a sample of lifelong intellectually disabled adults, (w:) V. Bissland, B. McKenzie (red.), A Legacy of Learning: Sharing Global Experiences of Learning in Later Life, Glasgow, University of Strathclyde, b.s.

Buys L., Aird R., Miller E. (2012), Service provider's perceptions of active ageing among older adults with lifelong intellectual disabilities, "Journal of Intellectual Disability Research", t. 56 (12), s. 1133-1147.

Buys L., Boulton-Lewis G., Tedman-Jones J., Edwards H., Knox M., Bigby C. (2008), Issues of active ageing: perceptions of older people with lifelong intellectual disability, "Australasian Journal on Ageing", t. 27 (2), s. 67-71.

Buys L., Tedman-Jones J. (2004), Barriers to autonomy for older adults with lifelong intellectual disability. Paper presented to the Social Change in the $21^{\text {st }}$ Century Conference. Centre for Social Change Research Queensland University of Technology 29 October 2004.

Coppus A. M. (2013), People with intellectual disability: what do we know about adulthood and life expectancy, "Developmental Disabilities", t. 18, s. 6-16.

Dykens E. M. (2013), Aging in rare intellectual disability syndromes, "Developmental Disabilities", t. 18, s. 75-83.

Hole R., Stainton T., Wilson L. (2010), Supporting aging adults with intellectual disabilities, (w:) V. Praser (red.), Contemporary issues in intellectual disabilities, New York, Nova Science Publishers, s. 87-90.

Innes A., McCabe L., Watchman K. (2012), Caring for older people with an intellectual disability: a systematic review, "Maturitas", t. 72, s. 286-295.

Jenkins R. (2010), How older people with learning disabilities perceive ageing, "Nursing Older People", t. 22 (6), s. 33-37. 
Judge J., Walley R., Anderson B., Young R. (2010), Activity, aging, and retirement: the views of a group of Scottish people with intellectual disabilities, "Journal of Policy and Practice in Intellectual Disabilities", t. 7 (4), s. 295-301.

Konarzewski K. (2000), Jak uprawiać badania oświatowe. Metodologia praktyczna, Warszawa, WSiP.

Krause A. (2010), Współczesne paradygmaty pedagogiki specjalnej, Kraków, Impuls.

Lehmann B. A., Bos A. E. R., Rijken M., Cardol M., Peters G-J.Y., Kok G., Curfs L.M.G. (2013), Ageing with an intellectual disability: the impact of personal resources on well-being, "Journal of Intellectual Disability Research", t. 57 (11), s. 1068-1078

Lifshitz H. (2002), Attitudes toward aging in adult and elderly people with intellectual disability, "Educational Gerontology", t. 28, s. 745-759.

Lifshitz H., Merrick J. (2004), Aging among persons with intellectual disability in Israel in relation to type of residence, age, and etiology, "Research in Developmental Disabilities", t. 25, s. 193-205.

Lifshitz H., Merrick J. (2003), Ageing and intellectual disability in Israel: a study to compare community residence with living at home, "Health and Social Care in the Community", t. 11 (4), s. 364-371.

Patti P. J., Amble K. B., Flory M. J. (2005), Life events in older adults with intellectual disabilities: differences between adults with and without Down Syndrome, "Journal of Policy and Practice in Intellectual Disabilities", t. 2 (2), s. 149-155.

Strydom A., Hassiotis A., Livingston G. (2005), Mental health and social care needs of older people with intellectual disabilities, "Journal of Applied Research in Intellectual Disabilities", t. 18, s. 229-235. 
SUMMARY

\section{Old age and ageing of people with intellectual disability}

A change in the form and way of life for persons with intellectual disability, which increases its quality (from a subjective and an objective point of view), entails systematic prolongation of this population's survival. Designing specific solutions supporting the elderly or preparing them for a favourable ageing process must be preceded by a thorough investigation of these individuals' needs. The following paper presents results of a study conducted with adult respondents with intellectual disability. Research problems included collecting data on (1) the knowledge and opinions of adults with intellectual disability about old age and ageing in the context of their personal experience with elderly people; (2) their ideas about their own future in the context of old age, including their preferred place and form of existence or activity.

\section{Keywords:}

old age, ageing, intellectual disability, knowledge, opinions 